\title{
Italian researchers in bid for fairer promotion rules
}

Munich. A 3,000-strong body representing Italian scientists has asked the government to introduce changes to the system of academic appointment, which it claims is open to corruption and abuse.

The Italian Federation of University Researchers has asked the cultural committees of Italy's new upper and lower houses, as well as new minister for universities and research, Stefano Podestà, for meetings to discuss the introduction of more rigorous assessment of applicants' academic qualifications.

Tenured academic positions in Italy are not awarded by individual universities, but through open concorsi (competitions) organized every few years by the ministry of research and universities in Rome. Applicants go through two stages. First, their academic achievements are considered by a subject committee. Short-listed candidates are then required to attend an oral examination, after which successful candidates are allocated to universities by the ministry.

Critics of the system complain that it is open to abuse, as there are no fixed criteria for the assessment made at either stage. They also say that members of assessment committees often use their personal influence to arrange support for particular candidates (see Nature 366, 293; 1994).

One result is that Italians who have worked abroad often find it difficult to get back into the system. This undermines the effectiveness of a 1985 modification to the concorsi law, which gave universities the right to apply for a 5 per cent increase in posts to attract academics working abroad back to Italy.

Carlo Bulletti, secretary of the federation, says it wants to see agreement on a set of minimum criteria for passing the first written stage of a concorso. According to Bulletti, too many people with poor publication records pass this stage, and too many of those are subsequently given posts.

Last December, says Bulletti, the cultural committee of the senate expressed its support for the proposed changes, but the government was near the end of its term and little could be done. He is optimistic that the new administration, elected on an anticorruption ticket, will be keen to tighten up the concorsi system by reducing the impact of personal influence on appointments.

The federation is planning an international workshop in December to define the criteria used to assess publication records including both the number of publications and their impact - that it would like to see introduced into the first stage of the concorso.

The government's unfulfilled promise to help native scientists working abroad to find full-time posts in Italian universities has worked out particularly badly for Canio Vosa, a botanist who was employed for 20 years in the plant sciences department of the University of Oxford in the United Kingdom.

In 1989, Vosa was offered a chair of botany at the University of Pisa under the government 'expatriate' rule. Vosa was in fact entitled to a professorship, having successfully participated in a concorso in 1979 , and being subsequently offered a job at the University of Rome.

Vosa left his post at Oxford in March 1991 and moved into a room and laboratory assigned to him at the University of Pisa. A few months later he was informed by the ministry of universities and research that his post at the top of the lecturer scale at Oxford did not fulfil the criteria of the new rule, which was restricted to senior lecturers only.

Despite written clarification of his former position by the University of Oxford which has only a single scale for lecturers and senior lecturers - and petitioning by the University of Pisa, Vosa has lost his chair in Pisa and is now out of work.

Alison Abbott

\section{Canada cuts role in space station, but boosts overall plans}

Quebec. Canada has announced details of a new long-term space plan that will allow it to reduce its financial contribution to the US international space station while maintaining full partnership along with the other 10 countries involved. But its rights to use the space station have, in return, been slightly reduced.

According to John Manley, the minister for industry, negotiations with the US National Aeronautics and Space Administration have resulted in a reduction of Canadian funding from a total of C $\$ 1.2$ billion (US\$880 million) to C $\$ 0.5$ billion over the next ten years.

Canada's overall space budget, on the other hand, has been increased to a $\mathrm{C} \$ 2.7$ billion over the same period. On top of $\mathrm{C} \$ 1.7$ billion of previously approved funds and a C $\$ 800$ million increase in last February's budget, this includes a further $C \$ 200$ million of new funds.

"As a result of this plan, Canada will by the year 2005 have four new satellites in orbit, Canadian astronauts will have participated in at least five shuttle missions, and Canadian robotics will have played a crucial role in the assembly of the space station," said Manley.

David Spurgeon

\section{US science to pay price if station proceeds}

Washington. Congress is ready to make science pay the price if the Clinton administration succeeds in bulldozing the increasingly friendless international space station through this summer's budget negotiations.

Actions by congressional committees over the past week suggest that the National Science Foundation (NSF) can expect at best an increase lower than the expected rate of inflation in the next financial year. The National Aeronautics and Space Administration (NASA) may be forced to make deep cuts in its science programme to keep the space station alive.

The NSF receives its money from the same Congressional pot, overseen by the veterans affairs, housing and urban development and independent agencies appropriations subcommittee, as NASA - and thus the space station.

The bad news for the science agency has come from the House subcommittee, chaired by Louis Stokes (Democrat, Ohio), which passed a budget giving it an overall increase of 3 per cent, compared to the 6 per cent requested by the administration. As Congress wants more NSF money spent on new buildings and equipment, the agency's research budget would grow by just $\$ 53$ million, against $\$ 185$ million requested.
These figures are bad news for NSF grant applicants, who already face a squeeze as their numbers expand against fixed budget ceilings. But the equivalent senate subcommittee, chaired by Barbara Mikulski (Democrat, Maryland) could produce even lower figures when it votes next month.

Last week, the senate subcommittee threatened NASA with a budget of $\$ 13.7$ billion, a drastic $\$ 600$ million short of the space agency's request. It also asked Dan Goldin, the NASA administrator, to choose whether to make such a cut by closing the Cassini mission to Saturn or the Advanced X-ray Astrophysics Facility (AXAF). Goldin will report back next week.

But some see Mikulski's $\$ 13.7$ billion as less of a serious proposal than a cry for help. If NASA's budget is set so low, House science committee chairman George Brown (Democrat, California) has said he will withdraw backing from the space station to save the rest of NASA's science programmes.

Mikulski, Brown and vice-president $\mathrm{Al}$ Gore - all space station supporters - have two weeks to sort out their differences before Tim Roemer (Democrat, Indiana) tries to kill the station on the House floor. Last year, it survived by 216 votes to 215 . 